\title{
Key Success Factors and Evaluation Criterias of e- Learning Websites for Higher Education
}

\author{
Pisit Prougestaporn, Thichakorn Visansakon, and Kultida Saowapakpongchai
}

\begin{abstract}
More than a decade ago, internet had gradually come to play a major role in the world as it was an advance technological tool provided several benefits to human being. Internet could also influence in educational field because it was the advance media to create distance learning in the form of elearning. In the meantime, e-learning could generate learning effective for higher education study and provide wider opportunity for students to enroll on higher education course due to students could access to learn anywhere and anytime without being required to attend the classrooms. However, there were several factors effecting to create successful elearning for higher education as well as several criterias possibly applied to evaluate the effectiveness. This paper therefore would be done to summarize the key success factors to create effective e-learning for higher education study, and review the applicable criterias to evaluate the effectiveness of e-learning for higher education. The methodology was to review the literatures, relevants previous studies, and survey from respondents include students and experts. The paper summarized that there were 4 key success factors to create effective e-learning for higher education study, and there were four main criterias to evaluate the effectiveness of e-learning for higher education.
\end{abstract}

Index Terms - Effectiveness, e-learning, evaluation criterias, factors, higher education,

\section{INTRODUCTION}

More than a decade ago, the World Wild Web or known as WWW for short became a new gateway to communicate. It also called Internet is a most popular thing and wild spread to almost every households. People are now communicate to each other and sharing information as fast as a matter of second. Due to the changing of technology, Internet became one of a valuable tool for distance learning. As the economy grew alongside the technology, distance learning has become one of a high profit margin in education industry.

E-learning websites is the advance developed tool in the twenty-first century which will generate new era of education under the concept of anyone can study in anywhere at any time. In the meantime, e-learning could generate effective of learning for higher education study and provide wider opportunity for students to enroll on higher education course due to students could access to learn anywhere and anytime without being required to attend the class in the university or college.

Many Universities and Colleges throughout the world

Manuscript received February 12, 2014; revised April 15, 2014.

Pisit Prougestaporn, Thichakorn Visansakon, and Kultida Saowapakpongchai are with the Srisakdi Charmonman Institute, Siam Technology College, Thailand (e-mail: pisit1979@hotmail.com, Meen.visansakon@gmail.com, Kultida1978@gmail.com). have turned their focuses from a traditional face-to-face classroom to a new way of learning at-home-base classroom, which fit many life who don't have the luxury of times, transportation, and importantly financial. Reference [1] indicates that since the middle of the 1990s, the number of colleges and universities which have provided courses and degree programs via e-learning mode has been growing dramatically.

However as many reasons from many researches and case studies, there are still many more strategies and models to develop under many circumstances throughout the learning process and preparation on both learners and administrators to which make the most successful in elearning for higher education. Reference [2] shows that there were several studies done previously mentioning about key success factors to e-learning for higher education E.G. Soong, Chan, Chua and Loh (2001); Graf and Caines (2001); Oliver (2001); Govindasamy (2005); and Vate-ULan (2008). In addition, to measure the effectiveness of elearning for higher education, there was several evaluation criterias required to use [3].

As a result, the major purposes of this paper were to summarize the key success factors to create effective elearning websites for higher education, and review the applicable criterias to evaluate the effectiveness of elearning websites for higher education. This paper was begun with the definition of e-learning and higher education. The key success factors to create effective e-learning for higher education together with evaluation criterias to measure the effectiveness of e-learning for higher education were reviewed. Then, the methodology, result, and conclusion of the paper were presented.

\section{E-LEARNING AND HIGHER EDUCATION}

E-learning was the transforming learning delivery where allowing to the reach online source of information which is the solution for individual study and can reduce the pride and stimulate the common coalition [4].

Higher Education was an educational level that follows a completion of a school providing a secondary education, such as a high school, secondary school, which normally include Under graduate and post graduate [5].

\section{KEY SUCCESS FACTORS TO E-LEARNING FOR HIGHER EDUCATION}

It is widely mentioned that e-learning occurs in a wide range of teaching activities where technology of one form or another is involved. Reference [6] shows that the insights gleaned from the study of QUALITY ON THE LINE 
demonstrated that the effected factors for e-learning environments were institutional support, course development, teaching or learning process, course structure, student support, faculty support, evaluation and assessment.

Reference [7] indicates that e-learning factors included intellectual property, suitability of the course for e-learning environment, building the e-learning course, e-learning course content, e-learning course maintenance, e-learning platform and the measuring success of e-learning courses.

In addition, an empirical study among college students suggested that a framework for the Critical success factors in online education focused on three aspects in e-learning includes technology, instructor and the previous use of the technology from a student's/perspective of students' previous computer knowledge [8].

Further more based on [9]-[13], it could be summarized the factors effecting to create success e-learning model for higher education into four main keys includes human deliberation, instructional design, technology development, and social delivery.

\section{A. Deliberation of Human}

In general, the term "human deliberation" combined by 2 words which were "Human" and "Deliberation". The term Deliberation itself referred as a process in which members of a community talk together about a common problem by considering different experiences and weighing the costs and benefits of various options for action in an effort to identify common ground [14]. So, Human deliberation could be considered as the process done by people which referred as people.

For e-learning model field, human deliberation therefore could be explained as the process done by belonging people in e-learning to participate in cost/benefit and various options of e-learning operation. Reference [9] shows that the key main factor effecting to create e-learning model for higher education was human factors in terms of technical competency of both instructor and student, e-learning mindset of both instructor and student, and level of collaboration between instructors and students. Reference [10] mentions that one key factor was the student participation to study. [11] states that two out of four major issues confronting the successful adoption and sustained use of e-learning in Australian higher education were belonged to human deliberation includes teacher expertise in online teaching, and student readiness to move online. In addition, factors effected for successful e-learning implementation were institutional support, student support, and faculty support [12]. And [13] states that one of the factors in HITS model for success e-learning implementation was human factor.

\section{B. Design of Instruction}

Reference [15] defines the term Instructional Design as the practice of maximizing the effectiveness, efficiency and appeal of instruction and other learning experiences. The process covered to determine the current state and needs of the learner, to define the end goal of instruction, and to create some intervention to assist in the transition. Generally, the process informed by pedagogically or adult learning tested theories of learning and may take place in student-only, teacher-led or community-based settings [15].
Reference [10] proposed six items of content robustness as the criteria to measure success e-learning that belonged to instructional design which referred to the degree to which the course content is available online, how it is structured, the use of images and graphics, and the degree of interaction among students and with the lecturer and the type and quality of student assessment. In the meantime, instructional design was one factor to implement success elearning [13]. Reference [11] states that one of the factors to support and sustain quality in e-learning programs illustrated was provision of content and learning resources and instructional designs. And, the factors effected for successful e-learning implementation were course development, course structure, and evaluation and assessment [12]. These could be classified as the factor of instructional design.

\section{Development of Technology}

Technological development was the process of research and development of technology which were expected to become generally applied in the near future [16]. Reference [9] states that one factor effecting success e-learning was perceived information technology infrastructure provided to teachers and learners. While, one of the key success factor to create sustained use of e-learning in Australian higher education was the factor regarding to technology infrastructure [11]. Then, in HITS model of success elearning implementation, technology was another factor proposed to implement success e-learning [13].

Finally [10] indicates that one of the effective factors to create success e-learning was technology used for encouraging degree of interaction among students and lecturer, and student participation to study.

\section{Delivery of Social}

The term social delivery generally referred as the output contributed by social to specific case, so it should be defined in terms of productivity, maintenance, and development of social toward specific case or idea [17]. This could be implied in e-learning as the contribution to create success e-learning for higher education from social factor.

Reference [10] proposes that there were some items in 10 items of academic rigor and 6 items of content robusness proposed for measuring success of e-learning that belonged to social delivery, such items as student participation, course content, course structure, , and answering resource. In addition, one of factor that belonged to social delivery which leads to sustain adoption of online learning for higher education in Australia was provision of content and learning resources given to students [11]. Then, [12] states that some factors affected for successful e-learning implementation belonged to social delivery as well, includes course development, and course structure. Finally, [13] classified social as one of the factor in terms of financial support, cultural support, learning content and language support for creating success e-learning.

These four key factors could create effectiveness of elearning for higher education once they were implemented together.

Reference [18] states that in order to create success elearning for higher education, all factors include human, 
technological, and social factor required to implement and process together simultaneously. Reference [9] recommends that to implement success e-learning, all factors identified either human or technology must be worked together.

\section{EVALUATION CRITERIAS}

For evaluation of effective on higher education provided, there were four major criteria applied to evaluate the performance of any operation includes cost efficiency, quality, service, and speed [19]. These criteria could be applied to evaluate the e-learning provided on higher education:

\section{A. Cost Efficiency}

One important part of the e-learning value was the sum of an ability to save money and how much do the benefit generate to the business (enhance skill and knowledge, improve job performance, and impact results). It was called cost efficiency.

\section{B. Quality}

Reference [20] states that there were four levels of quality includes reaction, learning, performance, and results. Reaction was the typical end-of-course evaluation or rating sheet, while Learning was the evaluation simply as tracking strategy, and Performance was the determination of the effectiveness in the e-learning system to ask e-learners who went through the online learning, finally results were often couched in a demand to prove that e-learning works and works better than others [20].

\section{Service}

Another important criterion area for e-learning is service, in terms of easy accessibility and the quality of access.

\section{Speed}

The last of the four criteria is speed. There are three major considerations: First, how quickly e-learning initiative is up and running (the development question). Second, how quickly can the e-learning initiative reach everyone who needs the content (the delivery question). And third, how fast can the e-learning initiative be altered due to a change in the business or the need to distribute new or revised information.

\section{Methodology}

All four key success factors of e-learning websites for higher education as well as four key evaluation criterias to measure effectiveness of e-learning websites for higher education reviewed in this paper were proposed to survey from two groups of sample which were students and experts. The classification of sample groups was relied on the previous research of [21]. There were 100 sample that students include e-learning students and perspective elearning students, and 12 experts working in Thai universities include e-learning experts and technical education experts. The questionnaire with likert scale questions were designed and let the sample respondents to rate their opinion. Mean analysis was selected to analyse the result.

\section{RESULT}

From the survey on key success factors to e-learning websites for higher education, it was summarized in Table I:

TABLE I: SUMMARY OPINION TOWARD KEY SUCCESS FACTORS

\begin{tabular}{|l|l|l|l|l|}
\hline \multicolumn{1}{|c|}{ Factors } & \multicolumn{2}{c|}{ Students } & \multicolumn{2}{c|}{ Experts } \\
\hline & Mean & Def & Mean & Def \\
\hline $\begin{array}{l}\text { Deliberation of } \\
\text { Human }\end{array}$ & 4.11 & Agree & 4.35 & $\begin{array}{l}\text { Strongly } \\
\text { agree }\end{array}$ \\
\hline $\begin{array}{l}\text { Design of } \\
\text { Instruction }\end{array}$ & 4.19 & Agree & 4.22 & $\begin{array}{l}\text { Strongly } \\
\text { agree }\end{array}$ \\
\hline $\begin{array}{l}\text { Development } \\
\text { of Technology }\end{array}$ & 4.25 & $\begin{array}{l}\text { Strongly } \\
\text { agree }\end{array}$ & 4.61 & $\begin{array}{l}\text { Strongly } \\
\text { agree }\end{array}$ \\
\hline $\begin{array}{l}\text { Deliver of } \\
\text { Social }\end{array}$ & 3.81 & Agree & 3.70 & Agree \\
\hline
\end{tabular}

Table I indicates that both students and experts viewed at least 3.41 mean scales in average of each key factors. It could be applied that both students and experts viewed positive opinion toward these key success factors reviewed, because both groups viewed at least agree toward each factors as (4.11 vs. 4.35) for human deliberation, (4.19 vs. 4.22) for instructional design, (4.25 vs. 4.61) for technology development, and (3.81 vs. 3.70 ) for social delivery. The result relevant to what previously done by [21].

For evaluation criterias, the table below represents the result:

TABLE II: SUMMARY OPINION TOWARD EVALUATION CRITERIAS

\begin{tabular}{|l|l|l|l|l|}
\hline \multicolumn{1}{|c|}{ Criterias } & \multicolumn{2}{|c|}{ Students } & \multicolumn{2}{c|}{ Experts } \\
\hline & Mean & Def & Mean & Def \\
\hline $\begin{array}{l}\text { Cost } \\
\text { efficiency }\end{array}$ & 4.21 & $\begin{array}{l}\text { Strongly } \\
\text { agree }\end{array}$ & 4.41 & $\begin{array}{l}\text { Strongly } \\
\text { agree }\end{array}$ \\
\hline Quality & 4.40 & $\begin{array}{l}\text { Strongly } \\
\text { agree }\end{array}$ & 4.56 & $\begin{array}{l}\text { Strongly } \\
\text { agree }\end{array}$ \\
\hline Service & 4.63 & $\begin{array}{l}\text { Strongly } \\
\text { agree }\end{array}$ & 4.55 & $\begin{array}{l}\text { Strongly } \\
\text { agree }\end{array}$ \\
\hline Speed & 4.71 & $\begin{array}{l}\text { Strongly } \\
\text { agree }\end{array}$ & 4.60 & $\begin{array}{l}\text { Strongly } \\
\text { agree }\end{array}$ \\
\hline
\end{tabular}

Table II indicates that both students and experts viewed at least 4.21 mean scales in average of each criterias. It could be applied that both students and experts viewed high positive opinion toward all evaluation criterias to measure the effectiveness of e-learning websites for higher education reviewed, because both groups viewed strongly agree level toward all criterias as (4.21 vs. 4.41) for cost efficiency, (4.40 vs. 4.56$)$ for quality, (4.63 vs. 4.55$)$ for service, and (4.71 vs. 4.60) for speed.

\section{CONCLUSION AND SUGGESTION FOR FURTHER STUDIES}

From the review of related literatures and previous researches as well as the survey conducted through that students and experts working in that university, it could be summarized that to create success e-learning websites for higher education, four key factors were required to concern include deliberation of human, design of instruction, development, and delivery of social. In addition, to evaluate the effectiveness of e-learning websites for higher education, it could be relied on four measurement criterias which were cost efficiency, quality, service, and speed.

The detail presented in this paper could be possibly applied to do further research by conducting survey with 
students and educational experts in other countries to seek their idea about key success factors and evaluation criterias of e-learning websites for higher education. Also, the detail presented in this paper could be applied to find out whether or not the key success factors and evaluation criterias could be used with e-learning websites for other level of educations like high school level.

\section{REFERENCE}

[1] M. Arrigo, "E-learning accessibility for blind students," Italian National Research Council - Institute for Educational Technology Via Ugo la, Palermo, 2005.

[2] K. Saowapakpongchai and P. Prougestaporn, "Web accessibility model for visually-impaired students on e-learning for higher education," International Journal of the Computer, the Internet and Management, vol. 20, no. 2, May - August 2012.

[3] K. Saowapakpongchai, "E-learning for disability students on higher education learning," Special edition of International Journal of the Computer, the Internet and Management, vol. 20, p. 2, December 1314, 2012.

[4] C. Sloan, e-learning, 2007.

[5] Wikipedia. (2010). Higher Education. [Online]. Available: http://en.wikipedia.org/wiki/Higher_education.

[6] The Institute for Higher Education Policy. (1999). Quality on the line: Benchmarks for success in internet-base. United States of America. [Online]. Available: http://www.ihep.org/Research/public-policy.cfm.

[7] R. Papp, "Critical success factors for distance learning," presented at the Americas Conference on Information Systems, Long Beach, CA, USA, 2000.

[8] T. Vollery, "Critical success factors in online education," The International Journal of education, 2000.

[9] M. H. B. Soong, H. C. Chan, B. C. Chua, and K. F. Loh, "Critical success factors for on- line course resources," Computers \& Education, vol. 36, no. 2, pp. 101-120, 2001.

[10] D. Graf and M. Caines, "WebCT exemplary course project," presented at the WebCT User Conference, Vancouver, 2001.

[11] R. Oliver, "Strategies for assuring the quality of online leaning Australian higher education," in M. Wallace, A. Ellis and D. Newton, Eds., Moving Online II Conference, Lismore: Southem Cross University, pp 222-231, 2001.

[12] T. Govindasamy, "Successful Implementation of E-Learning: Pedagogical Considerations," Internet and Higher Education, vol. 4, pp. 287-299, 2002.

[13] P. Vate-u-lan. (2008). Borderless e-learning: HITS Model for Web 2.0. [Online]. Available: http://ejournals.thaicyberu.go.th/index.php/ictl/article/view/59/62

[14] Partners of the Americas - Glossary. (2005). Deliberation. [Online]. Available:

http://www.partners.net/partners/Capacity_Building_EN.aspp.

[15] Wikipedia. (2009). Instructional Design. [Online]. Available: http://en.wikipedia.org/wiki/Instructional_design.

[16] B. Haller. (1996). Technological development. F\&E-Management. Vahlen, Muenchen. [Online]. p. 85. Available: http://en.wikipedia.org/wiki/Technology_developmentt.

[17] V. E. Holland, "Statement of the goals of the social service delivery system," Community Mental Health Journal, Springer Netherlands, 1974.
[18] P. Prougestaporn, K. Saowapakpongchai, and T. Visansakon, "Implementation of e-learning management operation model for higher education in Thailand," in Proc. the $10^{\text {th }}$ International Conference on E-learning for Knowledge-based Society, vol. 21, p. 2, December 12-13, 2013.

[19] M. Hammer and J. Champy. (2003). Reengineering the corporation: A manifesto for business revolution. Collins Business. [Online]. Available: http://imamu.edu.saa.

[20] D. Kirkpatrick. (1998). The four levels of evaluation. Evaluating Training Programs: The Four Levels. [Online]. Available: http://books.google.com.

[21] K. Saowapakpongchai, "The development of e-learning model for higher education in Thailand," in Proc. 2010 International Conference on Educational Network and Technology, Qing Huang Dao, China, 2010.

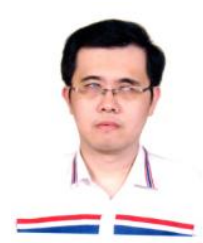

Pisit Prougestaporn was born in 1979 in Bangkok, Thailand. He earned bachelor of arts in business English from Assumption University of Thailand in 2004. IN year 2007, he earned master of science in management from College of Internet Distance Education, Assumption University of Thailand. And in year 2011, he earned Ph.D. in e-learning methodology from College of Internet Distance Education, Assumption University of Thailand. Currently, he is working as fulltime lecturer of Srisakdi Charmonman Institute, Siam Technology College, and deputy director of Siam Technology Internet Poll Research Center. He is interested to do research in educational technology, management, and marketing field.

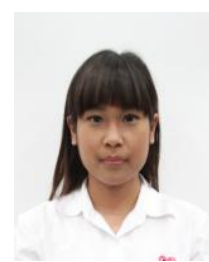

Thichakorn Visansakon was born in 1992 in Bangkok, Thailand. She earned bachelor of information and communication technology from Mahidol University, Thailand, in 2013. She is working as secretary to Srisakdi Charmonman Institute, Siam Technology College, and secretary to public opinion survey poll committee of Siam Technology Internet Poll Research Center. She is interested to conduct research in information, educational technology, marketing, and management.

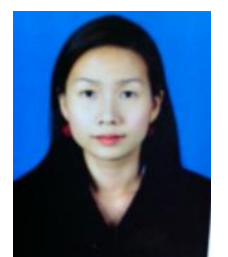

Kultida Saowapakpongchai was born in 1978 int Bangkok, Thailand. She earned bachelor of business information technology from chulalongkorn University, Thailand in 1999. She also earned master of business administration from Kasetsart University, Thailand in 2008. And in year 2011, she earned Ph.D. in e-learning methodology from College of Internet Distance Education, Assumption University. She is working as part-time lecturer of Srisakdi Charmonman Institute, Siam Technology, and deputy director of Siam Technology Internet Poll Research Center. She is also working as project manager at Sky Information Technology Co. Ltd. where operating the business on database management system installation service and consultant to both public and private organization. She is interested to do the research in information, educational technology, and management. 